\title{
Freedom of Travel and Exclusionary Land Use Regulations
}

The conflict between the goals of environmental preservation and relatively free access to communities has been fought for the past decade on the battleground of the exclusionary zoning cases. In these cases, the courts have balanced the general welfare of the region against the welfare of particular communities which sought to further their aesthetic and environmental values by limiting population growth through zoning.

There are indications that the battleground is about to shift. New attempts to preserve the environment by restricting access may be made through the use of the taxing and spending power, rather than through the police power, and future access claims may be based on the constitutional right to travel. To accommodate these important competing interests, this Note will recommend the adoption of a flexible right to travel test that will insure adequate judicial review of fiscal porver exclusionary measures but which will also protect legitimate and necessary local legislation. The first section of the Note will discuss the constitutional doctrine of freedom of travel. The second section will then apply the travel right to exclusionary zoning laws. Finally, the third section will consider various fiscal power exclusionary devices and how the courts might deal with them through the travel doctrine.

\section{Freedom of Travel}

\section{A. Freedom of Travel and Equal Protection}

Most of the Supreme Court's recent cases concerning freedom of travel have involved claims of a denial of equal protection. The seminal case in this line of decisions is Shapiro $v$. Thompson. ${ }^{1}$ There, the legislative classification was a one year residency requirement as a condition of eligibility for welfare payments, which penalized or discriminated against those welfare applicants who had recently moved into the state. The Court explicitly held that freedom of travel was a fundamental right, and therefore concluded that under the Equal Protection Clause the classification scheme had to further a compelling state interest. ${ }^{2}$ After stating that a governmental purpose to deter travel

1. 394 U.S. 618 (1969).

2. Under the traditional equal protection standard, the government need justify a classification by showing only some possible rational reason for the distinction. MicGowan v. Maryland, 366 U.S. 420 (1961). However, when the regulation creates a classification 
was impermissible, the Court found that the other state interests were not sufficiently compelling to justify the statute. ${ }^{3}$ This analysis has later been applied by the Court to invalidate similar residency requirements for voter eligibility ${ }^{4}$ and for the provision of public medical services to indigents. ${ }^{J}$

Shapiro is important because it clearly recognizes the existence of a fundamental right to travel. ${ }^{6}$ However, Shapiro and its progeny apply only to situations where the state has classified or discriminated against individuals on the basis of their exercise of this fundamental right. The equal protection analysis employed in these cases is inapplicable to other situations in which the right to travel is deterred or penalized.

In order to determine whether freedom of travel can be applied in contexts other than equal protection, and to formulate an appropriate

which is considered "suspect," such as race, McLaughlin v. Florida, 379 U.S. 184 (1964); when the classification denies one the exercise of a fundamental right, Kramer v. Union Free School Dist., 395 U.S. 621 (1969) (voting); or when the classification "penalizes" or discriminates on the basis of the exercise of a fundamental right as in Shapiro (travel); the government must demonstrate a "compclling state interest." For a discussion of more recent Supreme Court decisions in the equal protection area and an analysis of the futurc of the "two-tier" system, see Gunther, Foreword: In Search of Evolving Doctrine on a Changing Court: A Model for a Neu'er Equal Protection, 86 Harv. L. Rev. 1 (1972); note 24 infra.

3. 394 U.S, at 627 .

4. Dunn v. Blumstein, 405 U.S. 330 (1972). Dunn reaffirmed the holding in Shapiro and pointed out that actual deterrence of travel need not be shown when the state has classified individuals on the basis of the exercise of a constitutional right. Id. at 339.41. Sec Case Note, 1973 WIs. L. Rev. 914.

5. Sce Memorial Hosp. v. Maricopa County, 415 U.S. 250 (1974). The first major break in this consistent line of equal protection cases came in Sosna v. Iowa, $95 \mathrm{~S}$. Ct. 553 (1975), in which the Court upheld Iowa's one-year residency requirement for state divorce proceedings. The Court found that access to the divorce courts was "of a different stripe" than eligibility for welfare aid or medical treatment, and that Iowa's state interests outweighed any possible deterrence of travel. Prior to Sosna, numerous challenges to durational residency requirements for access to state divorce proceedings had been filed in state and federal courts. See, e.g., State v. Adams, 522 P.2d 1125 (Alas. 1974) and cases cited therein. As of May 1974, eight federal and state courts had upheld the residency requirements and four had invalidated them. $I d$. at 1127 .

6. 394 U.S. at 629-31,634. See also cases cited in Memorial Hosp. v. Maricopa County, 415 U.S. 250,254 n.7 (1974). The exact parameters of the right to travel are yet to be determined by the Court. In Shapiro, the Court dealt with travel in the sense of permanent movement to change residence, and did not consider the question of whether other, more temporary movement was also constitutionally protected. In Memorial Hospital, the Court emphasized that "[w]hatever its ultimate scope...the right to travel was involved in only a limited sense in Shapiro. The Court was there concerned only with the right to migrate, "with the intent to settle and abide'..." Id. at 25.4-55. Similarly, the Court has yet to decide whether freedom of travel includes intrastate as well as interstate movement. In Memorial Hospital, the Court refrained from deciding this point, but concluded that a county durational residency requirement for free medical care was unconstitutional because it penalized interstate travel. $I d$. at $255-56$. At least one court of appeals has concluded that intrastate travel is a "fundamental" right, King v. New Rochelle Municipal Housing Authority, 442 F.2d 646 (2d Cir.), cert. denied, 404 U.S. 863 (1971). See also Colc v. Housing Authority, 435 F.2d $80 \overline{7}$ (1970) (municipal residency requirement for public housing invalidated as an infringement on the right to travel, where one of the two plaintiffs had moved to the city from within the state); note 38 infra.

A discussion of the constitutional definition of "travel" is beyond the scope of this Note. For an claboration of these issues, see sources in note 7 infra. 
standard for such cases, it is necessary to concentrate on the earlier travel decisions of the Supreme Court and to draw analogies from precedents in other areas such as interstate commerce and First Amendment rights.

\section{B. Development of the Travel Doctrine}

The early development of freedom of travel had its roots in the Commerce Clause. ${ }^{7}$ The need for a free movement of both goods and people among the states was explicitly recognized in the Articles of Confederation, ${ }^{8}$ and although the right of "free ingress and egress to and from any other state" was not referred to in the Constitution, the Supreme Court has maintained the connection between travel and commerce.

Crandall v. Nevada, ${ }^{9}$ the first case explicitly to affirm the right to travel, dealt with a tax on the transportation of individuals out of a state. The Court analogized travel to interstate commerce, but concluded that the right to travel to the seat of the Government was a separate and distinct right. ${ }^{10}$ Although it was not alleged in that case that anyone was attempting to travel to Washington or any other federal office, the Court apparently concluded that the need for individuals to travel to the seat of their government was sufficient to justify a right to travel anywhere in the United States. ${ }^{11}$

In Edwards v. California"12 the Court abandoned the "seat of government" reasoning and instead relied solely upon the interstate commerce clause to invalidate a state statute which prohibited bringing indigents into the state. The language used by the Court, however, pointed to a higher interest than the free flow of goods. It emphasized the need for each state to face the social problems that beset all the

7. This Note will neither discuss in detail the historical foundations of freclom of travel, nor attempt to assign the doctrine to a particular clause of the Constitution. For a discussion of these issues, see $Z$. Chafee, Three Humin Rights in the Constitution $162-213$ (1956); Note, The Right to Travel-Quest for a Constitutional Source, 6 Rur.CAM. L.J. 122 (1974).

8. Articles of Confederation, art. IV (1781).

9. 73 U.S. (6 Wall.) 35 (1867).

10. 73 U.S. at 44 .

11. The Court relied on Chief Justice Taney's dissent in the Passenger Cases. Smith v. Turner, 48 U.S. (7 How.) 283, 492 (1849):

We are all citizens of the United States; and, as members of the same community, must have the right to pass and repass through every part of it without interruption, as freely as in our own States. And a tax imposed by a State for entering its territories or harbours, is inconsistent with the rights which belong to citizens of other States as members of the Union, and with the objects which that Union was intended to attain.

See Truax v. Raich, 239 U.S. 33, 42 (1915).

12. 314 U.S. 160 (1941). 
states, rather than to close its doors in an effort to isolate itself from those problems. ${ }^{13}$ In concurring opinions, Justices Jackson and Douglas urged the Court to declare explicitly that the right of free movement was a right guaranteed to all citizens as a necessary corollary of the federal system of government. ${ }^{14}$

But whether freedom of travel is called a separate federal right or an aspect of federal power over interstate commerce, both freedom of travel and interstate commerce serve the same purpose in slightly different areas. By providing for federal control over interstate commerce, the Constitution insured that economic problems could be tackled on a national scale, and that one state could not maximize its own economic welfare at the expense of the rest of the states. In the same way, the Edwards court, by allowing the free movement of the self-sufficient and the indigent alike, required that the problems of poverty and unlimited growth be confronted by the states as a whole, rather than as individual entities with the discretion to relegate the problems to other states. ${ }^{15}$

Of course, each state is still left with the power to handle its own

13. [T]here are boundaries to the permissible area of state legislative activity... And none is more certain than the prohibition against attempts on the part of any single State to isolate itself from difficulties common to all of them by restraining the transportation of persons and property across its borders. It is frequently the case that a state might gain a momentary respite from the pressure of events by the simple expedient of shutting its gates to the outside world. But, in the words of Mr. Justice Cardozo: "The Constitution was framed under the dominion of a political philosophy less parochial in range. It was framed upon the theory that the peoples of the sevcral States must sink or swim together, and that in the long run prosperity and salvation are in union and not division." Baldwin $v$. Seelig, 294 U.S. 511, 523.

314 U.S. at 173-74.

14. Justice Jackson stated:

This Court should, however, hold squarely that it is a privilege of citizenship of the United States, protected from state abridgement, to enter any state of the union, either for temporary sojourn or for the establishment of permanent residence therein and for gaining resultant citizenship thereof. If national citizenship means less than this, it means nothing.

314 U.S. at 183 (concurring).

In a separate concurrence, Justice Douglas asserted:

$[T]$ he right of persons to move freely from state to state occupics a more protected position in our constitutional system than does the movement of cattle, fruit and coal across state lines.

Id. at 177 .

15. The Edwards Court stated, for example, that

the theory of the Elizabethan poor laws no longer fit the facts. Recent years, and particularly the past decade, have been marked by a growing recognition that in an industrial society the task of providing assistance to the needy has ceased to be local in character. The duty to share the burden, if not wholly to assume it, has been recognized not only by State governments, but by the Federal government as well ....

What has been said with respect to financing relief is not without bearing upon the regulation of the transportation of indigent persons. For the social phenomenon of large-scale interstate migration is as certainly a matter of national concern as the provision of assistance to those who have found a permanent or temporary abode.

314 U.S. at $174-75$. 
economic and social problems as it sees fit, but its power does not extend to use of isolation as a method of dealing with those problems. Thus, a state may not maximize its own economic welfare by preventing the sale of goods made in other states. ${ }^{16}$ Similarly, a state may not prevent individuals of other states from entering to share in its economic or aesthetic good fortune. ${ }^{17}$ In both cases, constitutional doctrine has determined that the long term welfare is maximized by interaction and not by insulation.

\section{A Proposed Standard: The Balancing-Means Test}

No elaborate standard was necessary in Crandall or Edwards to protect freedom of travel; direct infringements such as absolute prohibitions or taxes upon travel caused the Court little trouble. The situation becomes more complicated, however, when state measures which are designed to promote the general welfare have the indirect effect of inhibiting travel. The Shapiro doctrine was developed to deal with one such impediment-a classification scheme, designed to promote a legitimate state objective, which penalized those who had engaged in travel. However, in contexts other than equal protection, courts need a standard by which to judge governmental action which does not directly involve or focus on travel, but which nonetheless hinders or inhibits this fundamental right. By analogy, the decisions of the Supreme Court in the Commerce Clause and First Amendment cases provide a standard to deal with these indirect burdens.

In situations where a state's exercise of its police power imposes a burden on interstate commerce or First Amendment rights, the Court has used a balancing test which weighs the effect on the federal interest or right against the state interest furthered by the regulation in question. In addition to balancing the relative importance of the interests, the Court has examined the means used by the state to insure that they do not unnecessarily interfere with the federal right or power.

This balancing-means standard developed slowly in the interstate commerce area. State and federal interests were often reconciled on the basis of artificial labels, instead of a realistic analysis of the particular factual situation in each case. ${ }^{18}$ Later cases, however, amply demon-

16. See Dean Milk v. Gity of Madison, 340 U.S. 349 (1951).

17. Edwards v. California, 314 U.S. 160 (1941); see notes 13-15 supra.

18. See generally G. Gunther \& N. Dowling, Cases and Materials on Constitutionat. LAW 614-58 (8th ed. 1970). When faced with state statutes which affected interstate commerce, the Court initially sought to determine whether the purpose of the statute was to deal with legitimate state interests or to regulate commerce, City of New York $v$. Miln, 36 U.S. (11 Pet.) 102, 132-38 (1837); whether the regulation affected a subject which was 
strate the use of the balancing-means standard. State safety or environmental interests are weighed against the burden upon the free movement of interstate carriers, and the regulations themselves are examined to insure that they further those state interests without making the commerce prohibitively expensive or exposing commerce to inconsistent regulations. ${ }^{19}$ The Court also scrutinizes the means adopted by the state to achieve its interest, and the regulation is held invalid if an alternative is available to the state which is less burdensome on interstate commerce. ${ }^{20}$

This same balancing-means standard has been applied in cases where the state seeks to further a legitimate interest in a manner which interferes with First Amendment rights. The Court has stated that the state interest must be "substantial" or "compelling" in order to counterbalance the First Amendment interest, and that the state must choose narrow and carefully "tailored" means to achieve this interest. ${ }^{21}$

"Iocal" or "national" in scope, Cooley v. Board of Wardens, 53 U.S. (12 How.) 299, 319 (1851); or whether the statute had a "direct" or "indirect" effect on commerce, Smith v. Alabama, 124 U.S. 465, 482 (1888), DiSanto v. Pennsylvania, 273 U.S. 34, 37 (1927), overruled, California v. Thompson, 313 U.S. 109, 115-16 (1941). In a prophetic dissent in DiSanto, Justice Stone suggested that the Court dwell less on such labels and instead weigh several factors, including "the nature of the regulation, its function, the character of the business involved and the actual effect on the flow of commerce..." Id. at 44.

19. See Southern Pac. Co. v. Arizona, 325 U.S. 761 (1945), in which the Court weighed the value of safety furthered by an ordinance limiting the length of trains against the possible disruption of interstate commerce:

The decisive question is whether in the circumstances the total effect of the law as a safety measure in reducing accidents and casualties is so slight or problematical as not to outweigh the national interest in keeping interstate commerce free from interferences....

Id. at 775-76; Colorado Anti-Discrimination Comm'n v. Continental Airlines, Inc., 372 U.S. 714, 718-22 (1963); Huron Portland Cement Co. v. Detroit, 362 U.S. 440, 443-44, 448 (1960); Bibb v. Navajo Freight Lines, Inc., 359 U.S. 520, 530 (1959). Such a balancing standard requires a case-by-case determination based on the particular facts of each case. Colorado Anti-Discrimination Comm'n v. Continental Air Lines, Inc., supra at 719. In general, however, the Court's main concern is whether the regulation in question creates the potential for significant conflicts with the regulation of other states. See, e.g., Bibb v. Navajo Freight Lines, Inc., supra at 529-30.

20. See Dean Milk Co. v. City of Madison, 340 U.S. 349, 354 (1951) (city cannot discriminate against milk imported from outside the state "even in the exercise of its unquestioned power to protect the health and safety of its people, if reasonable nondiscriminatory alternatives, adequate to conserve legitimate local interests, are available"); Bibb v. Navajo Freight Lines, Inc., 359 U.S. 520 (1959); G. GunTHER \& N. DowLING, supra note 18 , at $657-58$.

21. See, e.g., Police Dep't v. Moslcy, 408 U.S. 92, 102 (1972) (regulation must be "tailored to a substantial governmental interest" and not be discriminatory on the basis of content); Coates v. City of Cincinnati, 402 U.S. 611 (1971); United States v. O'Brien, 391 U.S. 367, 377 (1968) (regulation before the Court "furthers an important or substantial governmental interest" and "the incidental restriction on alleged First Amendment freedoms is no greater than is essential to the furtherance of that interest"); N.AACP v. Button, 371 U.S. 415,438 (1963) (there must be a "substantial regulatory interest"); Sherbert v. Verner, 374 U.S. 398, 403 (1963) (state interest must be "compelling"); Louisiana ex rel. Gremillion v. N.A.ACP, 366 U.S. 293 (1961); Shelton v. Tucker, 364 U.S. 479 (1960); Butler v. Michigan, 352 U.S. 380,383 (1954) (effect of the legislation before the Court is not reasonably restricted to the evil with which it is said to deal); Schneider v. State, 308 U.S. 147, 160 (1939) (state may not choose the regulation which is unnecessarily broad in application and restrictive of First Amendment rights); note 27 infra. 
By using this standard in the commerce and First Amendment areas, the Court is freed from the need to find the "true" purpose of the state regulation. The Court may accept the enunciated state purpose at face value and then determine for itself whether that purpose is best achieved by the challenged regulation. ${ }^{22}$ If it chooses, however, it may conclude that the purpose is unconstitutional because the obvious effect of the regulation is not to further the stated interests, but to inhibit constitutional rights. ${ }^{23}$

The use of the balancing-means standard in interstate commerce cases suggests that the same standard should apply to freedom of travel, given that the considerations favoring relatively unrestricted movement of goods also apply to movement of individuals. Furthermore, freedom of travel is a fundamental right, and, as indicated in the First Amendment cases, the balancing-means standard is invoked when state interests conflict with such rights. ${ }^{24}$ Moreover, recent dictum from the

22. In NAACP v. Button, 371 U.S. 415 (1963), for example, the Court found that the application of a Virginia champerty statute to the $\mathrm{NA.ACP}$ unduly restricted the freedom of association of the NAACP's members. The Court found that the state interests advanced by Virginia were neither sufficiently compelling nor narrow in scope to justify the inhibition of First Amendment rights. Because of this decision the majority found it unnecessary to "reach the considerations of race or racial discrimination" which were raised by petitioner. $I d$. at 444 . Justice Douglas, on the other hand, felt that the act "reflects a legislative purpose to penalize the N.A.ACP because it promotes desegregation of the races." Id. at 445 (concurring).

23. Cf. Griffen v. County School Bd., 377 U.S. 218, 231 (1964) (purpose of state statute allowing county to close public schools could only be to ensure segregated education); Gomillion v. Lightfoot, 364 U.S. 339, 441 (1960) (the Court, after cxamining the in: evitable effect of a town redistricting ordinance, stated that "the conclusion would be irresistable... that the legislation is solely concerned with segregating white and colored voters...."). See also Shapiro v. Thompson, 394 U.S. 618, 629 (1969) (an ordinance is unconstitutional if it has as its purpose the exclusion of indigents from the state).

24. The two-tier structure of the equal protection doctrine (see note 2 supa) may also be undergoing a shift toward the application of a balancing-means test. Instead of increasing the number of "suspect classifications" and "fundamental" rights, the Court has begun to determine for itself both the purpose of a state regulation and whether the classification achieves that purpose without unduly burdening the disfavored class. Thus, the Court seems to be steering toward a middle ground of required nexus betwcen the easily demonstrable "rational" nexus and the essentially undemonstrable "compelling" state interest. For examples of these trends, sec Stanton v. Stanton, $95 \mathrm{~S}$. Ct. 17(1) (1975); James v. Strange, 407 U.S. 128 (1972); Weber v. Aetna Cas. \& Surety Co., 406 U.S. 161 (1972); Eisenstadt v. Baird, 405 U.S. 438 (1972); Reed v. Reed, 404 U.S. 71 (1971); Gunther, supra note 2.

Such a relaxation in the rigid two-tier system of equal protection may result in a more flexible approach in durational residency cases. The recent case of Sosna $v$. Iowi, $95 \mathrm{~S}$. Ct. 553 (1975), may be the first in a series of steps in that direction. Instead of requiring a compelling state interest to uphold the state residency requirement for divorce, the Court applied a balancing approach which weighed the importance of the benefit denied to recent residents against the state interest in denying it. Indeed, the majority refrained from even using the two-tier termimology of "rational nexus" and "compelling state interest." The dissent clearly recognized this shift:

The Court's failure to address the instant case in these terms suggests a new distaste for the mode of analysis we have applied to this corner of equal protection law. In its stead, the Court has employed what appears to be an ad hoc balancing 
Supreme Court seems to support the notion that the right to travel is protected under a balancing-means test. In Dunn v. Blumstein,, the Court struck down a voting residency requirement as a violation of the Equal Protection Clause because it penalized those who had exercised their right to travel. But the Court went on to indicate that fundamental rights must not be inhibited by state regulations which do not further substantial interests and which are not narrowly drawn to minimize their effect on such rights. In support of that position, the Court cited NAACP $v$. Button, ${ }^{26}$ a major example of the use of the balancing-means test in a First Amendment context.

The balancing-means standard provides a flexible accommodation of the competing interests in the travel area. ${ }^{27}$ It enables the Court

test, under which the State's putative interest in insuring that its divorce plaintiffs establish some roots in Iowa is said to justify the one-ycar residency requirement.

Jd. at 567 (Marshall, J., dissenting). Thus it appears that the Court may eventually discard the equal protection terminology completely and simply weigh the rights involved against the state interests under a standard similar to that proposed in this Note, so that the same standard would be used for all freedom of travel cases. For a slightly different view of the appropriate standard in the different types of travel cases, see Note, supra note 7 .

25. 405 U.S. 330 (1972).

26. The Dunn court stated:

[T] he state cannot choose means that unnecessarily burden or restrict constitutionally protected activity. Statutes affecting constitutional rights must be drawn with "precision," NAACP v. Button, 371 U.S. 415, 438 (1963) ... and must be "tailored" to serve their legitimate objectives... And if there are other, reasonable ways to achieve those goals with a lesser burden on constitutionally protected activity, a state may not choose the way of greater interference. If it acts at all, it must choose "less drastic means."

405 U.S. at 343.

27. The reason the balancing-means test is used in either the interstate commerce or the First Amendment area is "not because some novel, particular rule of law obtains in cases of this kind," Shelton v. Tucker, 364 U.S. 479, 493 (1960) (Frankfurter, J., dissenting), but because it is the only way to accommodate conflicting interests. While the general method of analysis should always be the same, the strictness of the test will vary according to the interests to be reconciled. At one cxtreme, the test becomes the mere "rational nexus" requirement, where such a strong presumption of validity is given to the regulation in question that it will almost always be upheld. At the other extreme the test becomes one of "compelling state interest" where the regulation is essentially presumed to be invalid. The problem with both extremes is that they do longer represent modes of analysis, but instead are mere conclusory labels. What is needed is an explicit use of the balancing-means test where the strictness varies according to the substantiality of the competing interests.

In the interstate commerce area, where state interests are balanced against federal interests and no specific federal rights of individuals are jeopardized, the Court has enunciated a relatively lax means test. See Bibb v. Navajo Freight Lines, Inc., 359 U.S. 520,524 (1959):

These safety measures carry a strong presumption of validity when challenged in court. If there are altermative ways of solving a problem, we do not sit to determine which of them is best suited to achieve a valid state objective.

Nonetheless, the Court in Bibb struck down the state ordinance because it imposed a burden on interstate commerce and was not shown to be significantly more effective than alternatives which would not cause such a burden.

The balancing-means test is much stricter when fundamental First Amendment liberties are involved. In this area the state must act with "precision of regulation," NAACP $v$. Button, 371 U.S. 415, 438 (1963); the regulation must be narrowly drawn, Louisiana $e x$ rel. Gremillion v. N.A.ACP, 366 U.S. 293, 296 (1961); and "even though the governmental 
to consider the state interest that is protected by the type of regulation being challenged, and to balance the respective interests and assess the narrowness of the state's action in the particular circumstances of each case.

\section{Freedom of Travel and Exclusionary Zoning}

For the past decade, state courts have been aware of the fact that the police power can be an effective tool for inhibiting access to communities. Courts have struck down local zoning ordinances which limited growth in order to reduce financial expenditures or to maintain the rural or exclusive nature of the community. 2 s These ordinances are invalidated under the Due Process Clause, as interpreted by Justice Sutherland in Euclid \%. Amber Realty..$^{29}$ In exercising its

purpose be legitimate and substantial, that purpose cannot be pursued by means that broadly stifle fundamental personal liberties when the end can be more narrowly achieved," Shelton v. Tucker, supra at 488 . See note 21 supra.

In determining the strictness with which the balancing-means test should be used in the travel area, the application of the test in the interstate commerce and First Amendment cases provides the relevant parameters. On the one hand, the test should be at least as stringent as in the commerce area, because society values the free movement of people at least as much as it does the free movement of goods. See pp. 1566-67 supra. Moreover, mobility is essential to the national market sought to be protected by the Commerce Clause, in that it helps to ensure an available labor supply. On the other hand, freedom of travel, while a fundamental right, has never been held to occupy the "preferred position" that the First Amendment does. Travel does, however, promote First Amendment values by increasing associational opportunities, enhancing the ability to disseminate ideas, and protecting the right to petition the government for redress of grievances. See p. 1566 supra. Furthermore, the right to choose one's place of residence is an important value in itself, akin to the First Amendment objective of allowing individual self-fulfillment. See T. EMERson, Toward A General THEORY of tuE First AMENDMENT 4-7 (1966). This value is most important when people are striving for better opportunities and new employment, particularly since these people are usually very vulnerable to state exclusionary or inhibitory regulations. While of less importance, the right to seek a more comfortable place to live should also be protected to some degree. The economically and socially secure should have the opportunity to move to safe neighborhoods with good schools for their children, or to enjoy a vacation home in a scenic rural area.

In any particular freedom of travel case, the strictness of the means requirement and the ultimate result of balancing must depend on the substantiality of both the travel claim and the countervailing state policy. But in every case, the court should explicitly weigh the competing interests and examine the possibility of other, less burdensome means to further the local concerns, instead of basing its decision on conclusory labels.

28. See, e.g., Kavanewsky v. Zoning Bd. of Appeals, 160 Conn. 397, 279 A.2d 567 (1971) (lot size regulations); Lakeland Bluff Inc. v. County of Will, 114 Ill. App. 2d 267, 252 N.E.2d 765 (App. Ct. 1969) (restrictions on mobile homes); Bristow v. City of Woodhaven, 35 Mich. App. 205, 192 N.W.2d 322 (197I) (exclusion of mobile homes); Oakwood at Madison, Inc. v. Township of Madison, 117 N.J. Super. 11, 283 A.2d 353 (L. Div. 1971) (lot size requirements and restrictions on multiple units); Molino v. Miayor \& Council, 116 N.J. Super. 195, 281 A.2d 401 (L. Div. 1971) (restrictions on multiple units); Appeal of Girsh, 437 Pa. 237, 263 A.2d 395 (1970) (restrictions on multiple units); National Land \& Inv. Co. v. Kohn, $419 \mathrm{~Pa} .504,215$ A.2d 597 (1965) (lot size requirements); Town of Glocester v. Olivo's Home Court, Inc., 111 R.I. 120, 300 A.2d 465 (1973) (restriction on mobile homes); Board of County Supervisors v. Carper, $200 \mathrm{Va}$. 653, 107 S.E.2d 390 (1959) (lot size requirements).

29. 272 U.S. 365 (1926). 
police power, the state must further the "public health, safety, morals and general welfare" 30 if its actions are not to be considered an arbitrary deprivation of property. The courts have seized upon this language to require municipalities to zone in a "reasonable" manner which furthers the general welfare. They conclude that although it may be in the interest of the present residents to build walls around their communities and divert population movement, it is not in the general welfare of the region, which must accommodate those looking for housing: ${ }^{31}$

In each of these cases, the municipality asserted that the zoning scheme furthered an important community interest. In evaluating such claims, the courts rejected those reasons which were based on financial considerations or a desire simply to keep the community small. ${ }^{32}$ However, interests such as environmental preservation were considered to be important, justifiable goals. When such interests were presented, the courts engaged in a balancing test in which the community interests were weighed against both the landowners' right to the relatively unencumbered use of their land and the region's need for the accommodation of increased population. But the interests were not weighed in the abstract; the court only balanced the community interests as they were furthered by the means chosen. An ordinance would be invalidated if the court concluded that the means chosen either did not further the enunciated interests or that it furthered them in a manner which was unnecessarily restrictive of growth. ${ }^{33}$ In addition, the strictness of the means test depended on the importance of both the community interests and the access claim. Thus, a community which has unique ecological assets and which is faced with large numbers of people seeking to build vacation homes in the area would be allowed more freedom to choose its means of regulation than a subur-

30. Id. at 395 .

31. See, e.g., Oakwood at Madison, Inc. v. Township of Madison, 117 N.J. Super. 11, 20, 283 A.2d 353, 358 (L. Div. 1971); Golden v. Town of Ramapo, 30 N.Y.2d 359, 38393, 285 N.E.2d 291, 305-11, 334 N.Y.S.2d 138, 156-65 (Breitel, J, dissenting), appeal dismissed, 409 U.S. 1003 (1972). Appeal of Girsch, 437 Pa. 237, 245 n.4, 263 A.2d 395, 399 n.4 (1970); Bosselman, Can the Town of Ramapo Pass $A$ Law to Bind the Rights of the Whole World?, 1 FLA. ST. U.L. REv. 234 (1972).

32. See Kawanewsky v. Zoning Bd. of Appeals, 160 Conn. 397, 279 A.2d 567 (1971); Oakwood at Madison, Inc. v. Township of Madison, 117 N.J. Super. 11, 283 A.2d 353 (L. Div. 1971).

33. See National Land \& Inv. Co. v. Kohn, 419 Pa. 504, 215 A.2d 597 (1965) (invalidated Easttown's four-acre zoning requirement as an unreasonable means of achieving open space). The court found that the town could have provided open space by using cluster developments or condemning development rights, and that the minimum lot provision was chosen to keep down costs and preserve Easttown's scenic beauty for present residents. Id. at 529-33, $215 \mathrm{~A} .2 \mathrm{~d}$ at 610-13. 
ban community providing homes near places of employment. ${ }^{34}$ As in the interstate commerce and First Amendment cases, the courts in the zoning cases were not required to find an exclusionary purpose in order to strike down the ordinance. However, courts may conclude that the means chosen reflect such a purpose. ${ }^{35}$

Because the primary interest being served in the exclusionary zoning cases is residential access and the accommodation of population growth, the doctrine of freedom of travel should be applied to protect the ability of individuals to settle and abide in new communities and states. $^{36}$ One federal court has already ruled that a municipal plan

34. In Steel Hill Dev., Inc. v. Town of Sanbornton, 469 F.2d 956 (Ist Cir. 1972), the court upheld a six-acre zoning requirement in a portion of a rural community, concluding that the free access interest was not sufficient to counterbalance the town's environmental concerns. The court found that the developer in this case was not secking "to satisfy an already existing demand for suburban expansion, but rather [was secking] to create a demand in Sanbornton on behalf of wealthy residents of Megalopolis who might be willing to invest heavily in time and money to gain their own haven in bucolic surroundings." Id. at 961. Although it upheld the ordinance, the court nonetheless emphasized that "expansion of population, eren a very substantial one, seasonal or permanent," was not by itself a "Iegitimate basis" for the cxclusion of future residents. In addition, the court expressed concern that the town had sought to deal with its ccological problems in a "most crude manner" without the aid of any "professional or scientific study." Despite these facts, the court sustained the ordinance as a stopgap measure on the basis that, in the present state of uncertainty, the town's ordinance struck "the right balance between ccological and population pressures."

$7 d$. at 962 .

See County Comm'rs v. Miles, 246 Md. 355, 228 A.2d 450 (1967) (upheld a five-acre zoning requirement in seven percent of a county that was primarily waterfront and contained many buildings of considerable historical interest).

35. In Board of County Superv isors v. Carper, 200 Va. 653, 107 S.E.2d 390 (1950), the Virginia supreme court of appeals found that a two-acre zoning requirement in the western two-thirds of the county was not necessary to preserve ground water and public health, and that the ordinance served the purpose of channeling population into the castern portion "thereby preserving the western area for those who could afford to build houses on two acres or more." The court concluded that "[s]uch an intentional and exclusionary purpose would bear no relation to the health, safety, morals, prosperity and general welfare." $200 \mathrm{Va}$. at 66I, 107 S.E.2d at 396.

36. See Note, The Reconciliation of Land Use Lat's and the Right to Travel: Tou'ard a Realistic Slandard of Judicial Review, 31 WasH. \& LEE L. REv. 575, 594-603 (1974) (suggested that freedom of travel be applied to exclusionary zoning cases through the use of a "heightened rationality standard," which would require local ordinances to be consistent with regional patterns of natural growth).

The application of the freedom of travel doctrine in exclusionary zoning cases is not foreclosed by the decision of the Supreme Court in Village of Belle Terre $v$. Boraas, 416 U.S. 1 (1974), which upheld a town ordinance that allowed only single family dwellings. The plaintiffs' primary contention was that the ordinance violated the privacy and associational rights of unrelated persons who wished to live together. Brief for Appellees at 21-34. Although the plaintiffs raised the frecdom of travel issue, they did so only to emphasize the importance of their interest in living in the town. There was no allegation that the ordinance had either the purpose or effect of limiting the population of the town. The Court, in an opinion by Justice Douglas, concluded that the ordinance "is not aimed at transients" and "involves no fundamental right." 416 U.S. at 6. Thus, Belle Terre does not seem to resolve the right to travel issue in this area. See Margolis, Exclusionary Zoning: For whom does Belle Terre Toll?, II CaLIF. W.L. Rev. 85 (1974) (argues that Belle Terre was a First. Imendment rather than a right to travel case). 
which would artificially limit access to the community was a violation of the right to travel. ${ }^{37}$

In applying the freedom of travel doctrine to exclusionary zoning, the balancing-means test would be the proper standard. In many cases, this would be very similar to the test already used under the general welfare standard of due process. ${ }^{38}$ The freedom of travel doctrine is not merely a substitute for the general welfare test, however. Rather, it greatly expands the ability of the courts to deal with exclusion. First, the travel doctrine is adaptable to situations where the general welfare standard is inapplicable. For example, the legal requirements currently being applied to municipalities which limit growth would also apply to the states. If states were to adopt plans to restrict growth, the courts could require them to show that their reasons were substantial or compelling and that they had chosen the least restrictive means to achieve the desired purposes. In contrast, the general welfare approach is geared to maximizing the state's general welfare. Under that test, the interests of the municipality are balanced against those of the region or state. ${ }^{30}$ It is unlikely that the courts which rejected municipal zoning schemes because they were exclusionary would do the same when faced with a statewide statute that had an identical effect.

Another advantage of the freedom of travel approach is its applicability to those cases in which exclusion is achieved through means

37. Construction Indus. Ass'n v. City of Petaluma, 375 F. Supp. 574 (N.D. Cal. 1974) (growth plan which effectively limited the number of new housing units to 500 per year from 1971 to 1977). The court cited Shapiro and Dunn, and reasoned that "[i]nasmuch as there is no meaningful distinction between a law which 'penalizes' the exercise of a right and one which denies it altogether, it is clear that the growth limitation under attack may be defended only insofar as it furthers a compelling state interest." Id. at 582 (1974). The court then examined the interests put forward by the town-the need for adequate sewage facilities and water supply, and the inherent right of a municipality to control its growth. As to the municipal services, the court concluded that, under the Dunn mandate, the most tailored means had not been chosen (see note 26 supra) and that other, less restrictive means were available to solve the problems. Id. at 582-83. As to the other rationale, the court found that the municipality possessed no inherent right to control growth, citing Edwards (see notes $12-14$ supra) and the decisions of the Pennsylvania supreme court on exclusionary zoning (see notes 28,33 supra). Id. at 583-86.

Thus, although the court still used the terminology of Shapiro, it nonetheless applied freedom of travel outside the equal protection context, and in so doing engaged in an approximate balancing-means test similar to that used in the interstate commerce, First Amendment and exclusionary zoning cases. For a discussion of Petaluma in relation to other zoning cases, see Smith, Does Petaluma Lie at the End of the Road from Ramapo?, 19 Vill. L. Rev. 739 (1974); Case Note, 6 Seton Hall L. Rev, 207 (1974).

38. Indeed, in Construction Indus. Ass'n v. City of Petaluma, 375 F. Supp. 574 (N.D. Cal. 1974), the court relied in large part on exclusionary zoning cases in reaching its decision that the city's restrictive growth plan violated freedom of travel. See note 37 supra.

The court arrived at this result without deciding that the right to travel included intrastate travel. This result seems correct, since a municipal ordinance would inevitably affect those who were moving to the community from outside the state. See note 6 supra.

39. See p. 1573 supra. 
other than the police power. Although the Due Process Clause may be invoked to invalidate zoning regulations, its use is severely limited when the state relies upon its taxing or spending powers to limit growth. The Supreme Court has long held that a tax is presumed to be rational and that any attack upon its validity must be based upon either the tax's failure to raise revenue or its confiscatory nature. ${ }^{40}$ The Court is extremely reluctant to declare that a tax is a taking of property without due process of law or that it is a violation of equal protection. ${ }^{41}$ This presumption in favor of validity evaporates, however, when the tax is challenged as an infringement upon a specific federal right or power. ${ }^{42}$ Taxes which inhibit First Amendment rights, ${ }^{43}$ for example, or which affect interstate commerce ${ }^{44}$ are subject to closer scrutiny. Likewise, taxes which interfere with freedom of travel would not be presumptively valid. ${ }^{45}$

Finally, the freedom of travel doctrine is a more realistic approach than the general welfare test; it places the paramount interest squarely

40. This principle was clearly stated in Magnano Co. v. Hamilton, 292 U.S. 40 (1934), in which a 15 percent tax on the sale of margarine was sustained against due process and equal protection challenges. The Court held that "the due process clause contained in the Fifth Amendment is not a limitation upon the taxing power conferred upon Congress by the Constitution... and no reason exists for applying a different rule against a state in the case of the Fourteenth Amendment." Id. at 44. In addition, there could be no violation of equal protection unless the tax was "so arbitrary as to compel the conclusion that it does not involve an exertion of the taxing power, but constitutes, in substance and effect, the direct exertion of a different and forbidden power, as for example, confiscation of property." Id. Any requirement that the tax serve a public purpose "has regard to the use which is to be made of the revenue derived from the tax, and not to any ulterior motive or purpose which may have influenced the legislature in passing the act." Id. at 43. See also City of Pittsburgh v. Alco Parking Corp., 417 U.S. 369,373 (1974) (citing Magnano approvingly and stating that courts should refuse "either to undertake the task of passing on the 'reasonableness' of a tax that otherwise is within the power of Congress or of state legislative authorities, or to hold that a tax is unconstitutional because it renders a business unprofitable").

41. See, e.g., Lehnhausen v. Lake Shore Auto Parts Co., 410 U.S. 356, rehearing denied, 411 U.S. 910 (1973); accord, Austin v. New Hampshire, 95 S. Ct. 1191 (1975); Kahn v. Shevin, 416 U.S. 351, 355 (1974).

42. See Lehnhausen v. Lake Shore Auto Parts Co., 410 U.S. 356, 359 (1973):

Where taxation is concerned and no specific federal right, apart from equal protec-

tion, is imperiled, the States have large leeway in making classification and drawing

lines which in their judgment produce reasonable systems of taxation.

(emphasis added); Austin v. New Hampshire, 95 S. Ct. 1191 (1975); Allied Stores v. Bowers, 358 U.S. 522, 526-27 (1959).

43. See, e.g., Murdock v. Pennsylvania, 319 U.S. 105 (1943); Grosjean v. American Press Co., 297 U.S. 233 (1936).

44. See, e.g., Michigan-Wisconsin Pipe Line Co. v. Calvert, 347 U.S. 157 (1954),

45. For examples of taxes on travel that were not viewed as presumptively valid, see Evansville Airport v. Delta Airlines, Inc. 405 U.S. 707 (1972); Crandall v. Nevada, 73 U.S. (6 Wall.) 35 (1867). However, most taxes would probably not be invalidated as exclusionary devices. First, the tax must have a sufficient effect upon the ability of persons to travel or settle to outbalance the strong state interest in raising revenue. Second, in recognition of this important state interest, the courts should not apply a very strict means test in determining whether less burdensome alternatives to raise revenue are available. $S e e^{3}$ pp. 1574-75 supra. Nonetheless, under the freedom of travel doctrine, courts would at least have to consider the competing interests and the means used to achieve the state purpose, rather than simply immunizing taxing measures from judicial scrutiny. 
upon the right of individuals to move freely into communities. The present general welfare approach rests upon an artificial construction of the Due Process Clause. Justice Sutherland's admonition in Euclid was probably based on a desire to protect the landowner from an unreasonable limitation upon property rights. ${ }^{46}$ Because of this, in all of the exclusionary zoning cases, the ordinance is attacked by the landowner as an unreasonable taking of property without due process of law. ${ }^{47}$ Thus, if a landowner's monetary interests are not harmed by the zoning regulation, the court may well conclude that there has been no taking of property; $;^{48}$ and it may so conclude without any need to consider the interests of those who may desire access to the community, but who are effectively excluded by the zoning plan. In contrast, a court faced with a challenge based on freedom of travel would balance free access against legitimate local interests, without having to consider the effect of the ordinance on any particular landowner. The municipality's ordinance could thus be challenged by people outside the community as well as by those whose property was affected by the regulation. ${ }^{49}$

\section{Fiscal Power Exclusionary Measures and Application of the Balancing-Means Test}

In addition to zoning under the police power, state and local governments have a variety of fiscal tools which they might use effectively

46. See pp. 1572-73 supra. Although the Court was concerned with the effect of the municipal ordinance on "the general public interest," 272 U.S. at 390 , it first examined the question of whether the ordinance significantly reduced the value of the plaintiff's property. Id. at 384 .

47. In all of the cases cited in note 28 supra, the suit was brought by either the owner of the land or one who had an equitable interest in the land. See, e.g., National Land \& Inv. Co. v. Kohn, 419 Pa. 504, 513-14, 215 A.2d. 597, 603 (1965) (plaintiffs had standing because they had already expended more than $\$ 6,000$ in developing the land and had entered into an agreement to buy the land if a zoning change was made). See also County Comm'rs v. Miles, 246 Md. 355, 364, 228 A.2d 450, 454 (1967) (plaintiff landowners had standing to challenge the constitutionality of the local zoning ordinance because "it is more difficult to sell five acre lots than lots of three acres or less, and that the resale value of Blakeford, for development purposes, is decreased by its zoning classification"). In Oakwood at Madison, Inc. v. Township of Madison, 117 N.J. Super. 11, 283 A.2d 353 (L. Div. 1971), the stit was brought by both the developer and a group of potential residents in the proposed development. The court did not address the issue of whether the future residents alone would have sufficient standing to bring the suit.

48. The landowner need not show that the zoning ordinance is confiscatory in order to challenge its reasonableness. See Appeal of Girsh, 437 Pa. 237, 241 n.3, 263 A.2d 395, 397 n.3 (1970). However, the Pennsylvania supreme court considers deprivation to the landowner as the starting point in its analysis of the reasonableness of the zoning plan. Only after this deprivation is shown does the court proceed to determine whether the ordinance is in furtherance of the general welfare. National Land \& Inv. Co. v. Kohn, 419 Pa. 504, 524-25, 215 A.2d 597, 608 (1965).

49. Construction Indus. Ass'n v. City of Petaluma, 375 F. Supp. 574, 581.82 (N.D. Cal. 1974) (did not require the plaintiffs to show that they were landowners, but instead allowed a voluntary association of builders to sue). 
to limit growth, and each of these would be immune from review under the general welfare standard. One possible method would be a gains tax, which would tax the seller on the profits made from the sale of residential land or buildings. Such a tax could produce exactly the same exclusionary effect as a large acreage zoning requirement, in that both devices artificially increase the cost of moving into the community. A gains tax may be more popular with present residents, however, since the revenue it raised might allow a reduction in the annual property taxes. Those residents with no intention of moving would be benefited most by such a tax, but even those who planned to move sometime would approve of the plan if it included an exemption for those sellers who lived on the property they were selling. Such an exemption would place the entire tax burden upon those people who build new housing and those who buy that housing. In addition, the exemption would allow present owners to charge a higher price for their homes, since the increase in the cost of new construction would enhance the market value of the older residents. A similar technique would be to enact a simple transfer tax, based upon a certain percentage of the total sale price regardless of gain or loss. Like the gains tax, it could be designed so that only the developer and the owners of new homes would pay the tax, rather than the owners of existing dwellings. ${ }^{50} \mathrm{~A}$ third fiscal method of exclusion would be the creation of tax incentives, similar to those granted to farmers to maintain agricultural land. ${ }^{51}$ These incentives are generally viewed favor-

50. States clearly have this power. However, most municipal governments probably are not authorized to enact either a gains tax or a significant transfer tax. The constitutional and statutory schemes of many states contemplate annual municipal property taxes with certain percentage limits, but allow municipal transfer taxes only in particular circumstances and with strict percentage limits. See, e.g., N.J. STAT. ANN. \$ 54:4-1 (Supp. 1974); N.Y. Const. art. VIII; Ohio Rev. Code ANn. \$ 5705.03 (1973); Pa. Stat. ANN. tit. 53, $\$ 6902,6908$ (1972); VA. CodE ANN. $\$ \$ 58-758,760$ (1974). Pennsylvania, for example, permits municipalities to tax the transfer of real estate when the owner sells his home to a residential builder who is providing a newly built home for the seller, P.A. STaT. ANN. tit. $53, \S 6902(1)(1972)$, but the limit on this tax is one percent. PA. Siat. ANN. tit. 53, $\S 6903(5)(1972)$.

It is not inconceivable, however, that state legislatures might change such tax laws under sufficient pressure from residents of suburban communities. A recent example of this type of pressure is the New York state legislature's restriction upon the power it had previously given to the Urban Development Corporation to override local zoning laws in the planning of new residential developments. N.Y. UnconsoL. LAws \$6265(5) (McKinney Supp. 1973).

New Jersey's Governor Brendan T. Byrne is currently considering the use of a statewide real estate transfer tax. The tax is being considered as a method of raising revenue to allow the state to buy the development rights to land currently used for agricultural purposes. It is not clear, however, whether the tax is also meant to be part of a doubleedged weapon to limit development in the state by inhibiting the transfer of land. Newark Star Ledger, July 3, 1974, at 25, col. 1 .

51. Several states have enacted such farm zone taxation in an effort to preserve open space. The New Jersey Farmland Assessment Act of 1964, N.J. Srar. AnN. \$\$ 54:4-23.1 to 
ably as an effort to insure open space and greenbelts. But like all measures designed to preserve the environment, they may also be used to limit access to a community or state. Although the effect on the landowner would be beneficial, the effect on those wishing to move into an area would be the same as that of an ordinance which zones a large portion of a municipality as agricultural or residential, with five and 10 acre lot requirements. Furthermore, either independently or coupled with such a tax incentive for no development, tax reductions for developments of a particular density could be enacted. Under this approach, landowners who sold part of their land subject to restrictive covenants that set minimum acreage requirements for individual lots could receive a tax reduction on the remaining land they held. Finally, the town or state could choose to buy the land or the development rights, thereby enabling it to control future development. ${ }^{52}$

In order to illustrate the application of the balancing-means test to fiscal power exclusionary measures a statewide land gains tax will be used as an example. ${ }^{53}$ It will be assumed that the goals of such a tax are environmental preservation and revenue raising. Assume further that the tax rate depends on two variables: the length of time the land is held and the amount of profit made on the sale; the longer the land is held by the seller, the lower the rate, and the greater the profit, the higher the rate. Those sellers who have used their land as permanent residences are exempt from the tax. ${ }^{54}$ Finally the pro-

4-35. (Supp. 1973), for example, allows for the assessment of farmland at its farming value. In order to qualify, the land must be used for farm purposes for two successive years and it must be not less than five acres. For an early discussion of the feasibility of such plans, see Note, Techniques for Preserving Open Space, 75 Harv. L. REv. 1622, 1641-42 (1962). See also Sullivan, The Greening of the Taxpayer: The Relationship of Farm Zone Taxation In Oregon to Land Use, 9 WiLLAMETTE L.J. 1 (1973).

52. The American Law Institute's proposed Model Land Development Code contains a tentative provision on land banking which would grant condemnation powers to a State Land Reserve Agency for the purpose of "achieving the land policy and land planning objectives of [the] State." ALI MODEL LAND DEvelopMenr CODE, art. 6, 261-80 (Tent. Draft No. 6, 1974). See note 50 supra, for a discussion of land banking proposals in New Jersey. The possible use of land banking for exclusionary purposes has been recognized. See Note, Judicial Review of Land Bank Dispositions, 41 U. CHI. L. REv. 377, $381-82(1974)$.

53. In April 1973, Vermont enacted a statewide land gains tax. VT. STAT. ANN. tit. 32, $\$ \$ 5961-77$, 10001-10 (Supp. 1974). The Vermont tax, which applies only to land, $\$ 10001$, is sharply graduated; the longer the land is held, the lower the rate, and the greater the profit, the higher the rate. $\$ 10003$. For a discussion of the Vermont tax plan, see Note, 49 WASH. L. REV. 1159 (1974).

54. As originally enacted, the Vermont tax exempted only that land which the seller used as his principle residence, so that land which was sold for permanent homes, but which was newly developed, was subject to the tax. Law of Apr. 23, 1973, no. 81, § 10002, [1973] Vt. Stat., 5 Environ. L. INSTITUTE, ENviron. L. Rep. 43031 (Mar. 1975). This situation was changed when the act was amended to extend the exemption to all land "not exceeding five acres, necessary for the use of a dwelling which is to be used as the purchaser's principal residence." VT. STAT. ANN. tit. 32, $\$ 10002$. (emphasis added). 
ceeds of the tax are put in a property tax relief fund which, together with federal revenue-sharing funds, will be used for rebates to those who pay property taxes that are higher than a certain percentage of their annual income. ${ }^{55}$

The most obvious effect of the tax will be to reduce land speculation drastically. ${ }^{56}$ Speculators buy land for the sole purpose of resale and they rely upon a relatively rapid turnover of land in order to avoid an accumulation of property taxes and interest on purchase money mortgages. ${ }^{5 \tau}$ Under the gains tax, however, the large profits and short holding periods would subject the speculator to a high tax rate. In addition, the speculator would find it difficult to procure a buyer, since a developer (who is the most likely purchaser) would also be subject to the tax upon sale of the finished parcels.

It is this effect on the developer which results in a limitation on access to the state. A developer, like a speculator, relies upon the rapid resale of land. Interest costs, property taxes, and the need for immediate cash flows compel the developer to subdivide immediately and begin selling completed parcels as soon as possible. ${ }^{58}$ However,

This change greatly reduced the exclusionary effect of the tax by exempting developers from the tax when they sell homes which will be used by the purchasers as principal residences. The individual who sells the land to the developer, however, will still be subject to the tax, and some of this added cost will be passed on to the developer. The tax also applies to the sale of land for vacation residences. It was the original intent of Governor Salmon that the tax should apply only to these residences and that it include both land and buildings. Such a tax was thought to be sufficient to deter speculation and reduce development in the state. Letter from Norris Hoyt, Governor Salmon's tax advisor, to George F. Carpinello, Nov. 26, 1973.

55. The Vermont plan, in fact, provides for such a distribution of funds. Whatever revenues are derived from the gains tax will be used, in combination with General Revenue-Sharing Funds (pursuant to 31 U.S.C. $\$ \S 1221-63$ (Supp. 1972)) to provide property tax relief to permanent residents. This unique credit plan ensures that most residents will pay property taxes no greater than a set percentage of their households' annual in. come. The percentage each household will pay varies from four to six percent, depending on income. In no case, however, would the household be entitled to a credit greater than $\$ 500.32$ VT. STAT. ANN. tit. 32, $\$ \$ 5961-77$ (Supp. 1974).

56. The primary purpose of the Vermont tax plan is to deter land speculation. See note 54 supra.

57. See M. Seldin \& R. Swesnik, Real Estate Investaient Strategy 122-24 (1970), cited in Walker, Some Observations on Land Falue Taxation, TAx PoLIcr, June-July 1971 , at 6-8.

58. See Waxman, Financing of Land Investment, 7 REAL EsTATE LAW AND PRActice 87, 91-102 (PLI Transcript Ser., 1969). Waxman discusses at length the need for an early cash flow in order to induce noninstitutional lenders to finance the project:

In most cases the secondary lender will not make the loan when the land is not ready

for development because of the costs of carrying land indefinitely at high interest

rates and because the lender can see no ... immediate source of repayment. Id. at 93 .

See also Martin, Remote Land: Development or Exploitation, URBAN LAND, Feb. 1971, at 6, where the nature of recreational development is discussed:

All of the developer's efforts are designed to sell as many lots as he can in the shortest possible time, deferring as much of the project's major construction costs for as long as possible in order to generate a positive cash flow quickly.

This need for an immediate cash flow is not a problem solely for a small developer. In 
the gains tax would force the developer to delay his sales to the point where the costs of waiting begin to exceed the tax payments. Of course, some or all of the increased costs might be passed on to the home buyer, depending on the demand for housing. But whatever the elasticity of demand, the inevitable effect would be some combination of higher prices for homes and less construction.

Although such an increase in the cost of housing would inhibit migration into the state, this cost might be offset by the savings gained from the property tax relief plan. However, the amount of savings that would accrue is not clear. For some residents, particularly those in the upper income brackets, the measure would provide no relief. For others, the savings could be pitifully short of the increased cost of their homes; and even if they recouped the added cost, the savings in later years would not help them meet the relatively immediate cost of purchasing their home. In addition, the tax relief would not benefit highly mobile residents who had left the state before the savings became available. ${ }^{58}$

Faced with evidence of a reduced ability to move into and settle in a state, a court would have to determine if legitimate state interests outweighed the burden on travel and if alternative means would further the state interest without being unnecessarily burdensome on travel. ${ }^{00}$ Certainly the reduction in overall development caused by the gains tax would ease pollution problems and leave a greater proportion of the state's land in its natural state. However, a statewide tax would apply equally in all areas, thereby discouraging development in urban areas and forest lands alike. Such a plan would not be particularly effective in singling out those areas in need of special protection, and therefore would be unnecessarily burdensome on access

their study of large-scale developments, planning experts Gladstone and Wilburn constructed a hypothetical "prototypical large multi-use project" to illustrate how large-scale developments are financed. In the model, the land and buildings were being sold as soon as possible after acquisition in order to generate sufficient cash flows, and six years after acquisition approximately one-half of the residential land had been sold. Wilburn \& Gladstone, Optimizing Development Profits in Large Scale Real Estate Projects, URBAN LAND INsTrTUTE Technical Bulletin No. 67, 1972, at 44-47.

59. Moreover, since the land gains tax would probably raise the price of all housing in the state, it would also raise the assessed value of each home. Thus, some people would not only fail to receive a tax rebate, but might also have to pay a higher annual property tax.

60. The Vermont tax, as originally enacted, was challenged unsuccessfully by a group of developers. Andrews v. Lathrop, 132 Vt. 256, 315 A.2d 860 (1974). The plaintiffs alleged that the tax violated their rights to due process and equal protection. The Vermont supreme court easily rejected these claims, relying upon the many precedents that require considerable judicial restraint when taxes are challenged under either of those clauses. See p. 1576 supra. The plaintiffs apparently did not consider a claim based on freedom of travel, although they did allege that the tax deterred citizens from other states from buying and selling land in Vermont. Brief for Appellants at 19-20. 
to the state. ${ }^{61}$ One way that environmental preservation could be better achieved is by a well-tailored state zoning plan..$^{62}$ Such a plan could, for example, allow high-density development while providing open space by means of cluster zoning. ${ }^{63}$ In addition, it could tailor the uses to the types of land: town houses in urban areas, more single family residences in urban fringes, and relatively little development in special ecological preserves. A carefully drafted zoning scheme would limit development only in those areas where the possibility of environmental damage was a real concern. Clearly, the use of such a zoning scheme would also limit access to the state, but it would be free from challenge under the balancing-means test because it would further substantial environmental interests in a way that would not be unnecessarily burdensome on travel. ${ }^{64}$

Those challenging the gains tax would also have to show that the revenue-raising interests of the state did not outbalance the limitation upon access. Maintaining its fiscal integrity is of paramount concern to the state. Yet, the means chosen in this case do not substantially further that goal. Increment taxes-i.e., taxes levied at the time of transfer-are by nature peculiarly poor devices for raising revenue. Once the rate is raised high enough to insure sufficient revenue, land is traditionally withheld from the market. ${ }^{65}$ Moreover, rather than rais-

61. It has been argued that the Vermont land gains tax, by deterring speculation and the rapid turnover of land, furthers four public objectives: reducing accelerated and inefficient development, helping to preserve community aesthetic values, taxing windfall profits, and decreasing the pressure on land prices and resultant property taxes. Note, 49 WASH. L. Rev. 1159, 1161-65. But the first two objectives may be deait with more directly through land use regulations which prescribe the location and character of development. The third objective could be furthered by a simple windfall profits tax. Finally, the fourth objective is not in the general welfare if what is sought is an escape from the costs of population growth. See note 66 infra. Moreover, if the state wishes to ease the burden of property taxes on certain of its residents, it may readjust its revenue-raising activities in numerous ways that are less burdensome on access and the right to travel.

62. Vermont has already enacted a statewide zoning plan, Vr. STAT. ANN. tit. 10, $\$ \$$ 6001-89. (Supp. 1974), which divides the state into various zoning districts and requires the developer to meet several environmental and health conditions before developments of a certain size can be built. For a discussion of the Vermont plan, see E. BosselMAN \& D. Callies, The Quiet Revolution in Land Use Control (Council of Environmental Quality 1971).

63. Compared to usual zoning plans, cluster zoning is "a more flexible form of residential subdivision" in which "the number of houses is about the same, but they are clustered more closely together in order to release the remainder of the land for use as shared open space." K. Kulaiala, Cluster Zoning in MAssachusetTs 1 (1970). For an example of judicial approval of such zoning, see note 33 supra.

64. This conclusion is not inconsistent with the prior discussion of exclusionary zoning. See pp. 1572-74 supra. Those zoning plans prevented rather than accommodated growth, and therefore unnecessarily interfered with access. In contrast, the statewide scheme outlined in the text would be narrowly drawn and would strike a reasonable balance between growth and environmental preservation.

65. The British experimented with an increment tax in the early part of this century and again after the Second World War. Both times, the plan was eventually rejected be- 
ing additional revenue, the gains tax merely effects a redistribution of funds from the future residents to the present ones. Whatever revenue is raised by the tax will be used to grant property tax relief to present residents. These residents would thus receive a property tax bonus solely because new residents would be forced to pay more for their homes. Current residents would also reap a further tax bonus at the expense of those deterred from moving to the state. Property tax burdens would be lower because a decrease in the number of new residents would reduce the need for new public facilities. In effect, then, the tax would be a means whereby the present residents could escape the costs of growth, and that is a goal which is insufficient to justify a burden on access. ${ }^{66}$

\section{Conclusion}

This Note has been an attempt to show that the right to travel exists as an independent right outside the equal protection context, that it is applicable to cases involving exclusionary land use regulations based on the police or fiscal powers, and that it has major advantages over the general welfare standard for dealing with such exclusionary measures. A balancing-means standard was proposed for evaluating governmental action that has the effect of inhibiting the ability of persons to travel and settle in a new municipality or state. Under this standard, a state or locality would have to show that the legislation in question furthered substantial state interests and was not unnecessarily burdensome on the right to travel.

cause landowners withheld land from the market to avoid the tax. See Ilersic, Land V'alues and Levies in the U.K., 26 CANADIAN TAX J., 416-19 (1968), cited in Walker, Taxation of Land Value Increases, TAx PolicY, Aug.-Sept. 1971, at 9. See D. NETZER, Economics OF THE Property TAX 212-13 (Brookings Institution 1966):

Revenue from the tax, if levied only at the time of transfer of ownership, cannot be large enough to form a complete replacement for the present property tax: if the rate is low, the yield will be minor and if high will encourage owners to postpone realization.

66. See, e.g., Oakwood at Madison, Inc. v. Township of Madison, 117 N.J. Super 11, 283 A.2d 353 (L. Div. 1971), in which the town sought to reduce or limit the tax burden upon the present residents by restricting the number of multiple-unit dwellings and increasing the minimum lot size requirements. By thus limiting access to the community, the present residents hoped to keep down the expenditures which were needed to accommodate future residents. The court found such an interest irrelevant to general welfare goals and hence outweighed by the need for accommodation of increased population in the region. See also Southern Burlington County NAACP v. Township of Mount Laurel, 43 U.S.L.WV. 2399, 2400 (N.J. Sup. Ct. Mar. 24, 1975). 
The ultimate responsibility for defining and protecting the constitutional right to travel rests with the judiciary. Precedents in other areas give guidance to the courts as to how this responsibility should be fulfilled. The use of the balancing-means test in the commerce and First Amendment cases provides the parameters within which travel claims may be evaluated, and the many exclusionary zoning cases illustrate how the travel right may be balanced against local interests in the context of land use regulation. The important point, however, is that the interests in every case should be balanced according to an explicit and practical standard. Only in this way can the competing individual and societal interests be reasonably accommodated. 